December 2008

\title{
Theorizing Destruction: Reflections on the State of Comparative Genocide Theory
}

Maureen S. Hiebert

Follow this and additional works at: https://digitalcommons.usf.edu/gsp

\section{Recommended Citation}

Hiebert, Maureen S. (2008) "Theorizing Destruction: Reflections on the State of Comparative Genocide Theory," Genocide Studies and Prevention: An International Journal: Vol. 3: Iss. 3: Article 6.

Available at: https://digitalcommons.usf.edu/gsp/vol3/iss3/6

This Articles is brought to you for free and open access by the Open Access Journals at Digital Commons @ University of South Florida. It has been accepted for inclusion in Genocide Studies and Prevention: An International Journal by an authorized editor of Digital Commons @ University of South Florida. For more information, please contact digitalcommons@usf.edu. 


\title{
Theorizing Destruction: Reflections on the State of Comparative Genocide Theory
}

\author{
Maureen S. Hiebert \\ Centre for Military and Strategic Studies \& Department of \\ Political Science, University of Calgary
}

\begin{abstract}
This article reviews the current state of comparative genocide theorizing, focusing on theories that attempt to account for the causes of genocide and the processes of genocidal killing. The literature is divided into three broad categories, based on the relative weight given to (a) individual or group agency, (b) structural factors, or (c) processes of identity construction in accounting for the origins and unfolding of genocidal destruction. The discussion of agencyoriented approaches focuses on theories that suggest that genocide is driven, in terms of decision making and perpetration, by elite decision makers, front-line perpetrators, and societal behavior. The literature on structural approaches is broken down into theories that stress the importance of culture, institutional organizations, societal cleavages, structural crises, regime type, modernity, and ideology. The final section reviews the literature on processes of collective identity construction. The article suggests throughout and in conclusion that although comparative genocide theorizing has come a long way in proposing a number of different explanations for the onset of genocide and the nature of genocidal processes, more work needs to be done with respect to the precise operationalization and testing of theories according to more rigorous comparative methodological practices.
\end{abstract}

Keywords: comparative genocide, genocide theory, genocide studies, Holocaust and genocide, mass killing

\section{Introduction}

Comparative genocide studies is a young discipline that seeks to understand an "old scourge." As the post-Holocaust plea "never again" consistently went ignored in the latter half of the twentieth century, scholars in the social sciences and humanities began to examine the origins and processes of what is arguably the worst form of collective human behavior and to try to answer the vexing question of why human beings do such terrible things to each other "again and again." Much of what we now call "genocide studies" began with single case studies of individual genocides, but in the 1980s a small group of scholars began to engage in the comparative analysis of multiple cases of genocide, in the hope of uncovering the underlying logic of this terrible crime. Given the very real human suffering attached to the subject, comparative genocide studies has evolved not only into an academic discipline concerned with understanding and explaining past genocides but also into a goaloriented research project aimed at preventing the perpetration of genocidal violence in the present and future.

This article focuses on the current state of comparative genocide theory, ${ }^{1}$ specifically the creation of theories intended to account for the causes of genocide 
and the processes of genocidal destruction. It does not cover the considerable body of literature concerning the definition of the concept of genocide and what cases of mass atrocities ought to be considered as such. The state of the genocide literature in this respect has been well rehearsed elsewhere and, therefore, need not be further rehearsed here. More importantly, however, the issue of definition is omitted from the current discussion because the fixation among genocide scholars on how to define genocide has diverted needed attention away from the creation and testing of theories. Of course, defining core concepts is a central and necessary part of the theorizing process, but it is not a substitute for theory or theorizing itself. The obsession with definitional debates has arguably left comparative genocides studies undertheorized relative to other disciplines in the social sciences and humanities. $^{2}$

What this article does do is attempt to categorize and critically evaluate the most prominent theoretical approaches used to explain the origins and processes of genocide. The list of approaches and authors considered is, admittedly, far from exhaustive. Reviewing the theoretical literature on genocide is somewhat difficult, given the interdisciplinary nature of the field and the lack of a unified theoretical or methodological approach, an agreed-upon set of cases, or a preferred level or unit of analysis. ${ }^{3}$ The lack of theoretical and methodological coherence in the field is not necessarily a problem, however. Genocide is not only a horrible phenomenon, it is also an exceedingly complex one that occurs across a wide variety of times and places and involves different kinds of collective actors (perpetrators, victims, bystanders, collaborators, rescuers, etc.) and a number of different variables, structures, and processes that do not fit neatly into simple, generalizable explanatory models. The heterogeneity of theoretical and disciplinary approaches we find in genocide studies may be entirely appropriate for a discipline that studies one of the most convoluted and seemingly unfathomable forms of human activity. The failure of past grand theories in the social sciences to predict many of the seismic changes of the past century should also serve as a cautionary tale to comparative genocide scholars.

The review that follows does not divide the literature into disciplinary approaches, in order to allow us to consider the evolution of theorizing in the field as a whole. Instead, for the sake of clarity, the literature is categorized according to the relative weight given to individual or group agency, structural factors, or processes of identity construction in accounting for the origins and unfolding of genocidal destruction. This approach allows us to concentrate on what individual authors and approaches suggest is the initial source of the complex web of events, individual and collective actions, and processes that produces genocide. Admittedly, this way of categorizing the literature imposes on it a somewhat artificial structure, since many approaches either imply or explicitly state a reciprocal or mutually constitutive relationship between human agency, structure, and process. Nonetheless, the initial discussion of agency-oriented approaches focuses on theories that suggest that genocide is driven, in terms of decision making or perpetration, by elite perpetrators, frontline perpetrators, or societal behavior. Next, structural approaches are considered; in this section the literature is divided according to whether the theories espouse stress the importance of culture, institutional organizations, societal cleavages, structural crises, regime type, modernity, or ideology. The final set of approaches considers processes of collective identity construction, namely the conception of the victim group as the "other," as subhuman, and as a threat. 


\section{Theories of Genocide}

\section{Agency-Oriented Approaches}

\section{Elites}

One way in which scholars have tried to explain genocide is to look at the role played by elite decision makers. For some authors who use this approach, analysis focuses on the role played by specific individual leaders, from Hitler to Stalin to Pol Pot and others, in the genocidal process. Here the argument is that the most senior decision makers, for reasons of personal psychology, life and leadership experience, or ideological beliefs, make the decision to exterminate whole groups of people, which makes these individual leaders the ultimate source of genocidal policies. Some works, such as Gerald Fleming's Hitler and the Final Solution, ${ }^{4}$ were written explicitly to counter the claims of genocide deniers and minimizers that specific elites, in this case Hitler, did not sanction the killing, were lied to about it by their subordinates who were really to blame, or simply were not aware of what was happening to the victims. Other works are not specifically about a genocide at all but, rather, are biographical histories that shed light on several aspects of an individual leader's life, public and private, including his role in committing genocide. ${ }^{5}$ As largely ideographic (i.e., single-casestudy) historical works, these explanations tell us in great detail the role played by specific historical figures in the initiation and perpetration of genocide, but they also raise a more general comparative question: Are genocides primarily the result of the actions of individual leaders? Would the Holocaust have happened without Hitler, or the "killing fields" without Pol Pot? Is there a not-so-great-man theory of genocide? The answer to this question is that we simply do not know. Although senior political elites are central to the genocidal decision-making process, we cannot turn back the clock and factor out individual leaders from the equation to see whether a given genocide would have happened without them. As a basis for comparison, it is counterproductive to extrapolate from single case studies of individual leaders the idea that these leaders are the only significant actors in the genocidal process. The role of individual elites in a particular genocide may be highly idiosyncratic and, therefore, not comparable to those of other elites in other cases.

Leaving the influence of specific historical figures aside but maintaining the focus on elite agency, recent works by Benjamin Valentino and Manus Midlarsky, for example, have adopted a strategic actor model to account for the conditions under which elite actors make the decision to commit genocide. ${ }^{6}$ Valentino sees genocide, or what he calls "mass killing," as a barbaric, immoral, and seemingly illogical act but one that is the product of a rational choice made by elites to achieve specific policy goals. For Valentino, genocide is not an end in itself but a strategic means to achieve an end. In the pursuit of radical policy goals, perpetrator elites commit genocidal violence against a target group in order to force its members to do something they would otherwise not do but which is required for the realization of specific policy goals. The decision to commit genocide is made only when elites have concluded that other, less violent forms of repression or concessions to the target group for achieving their ends have failed or are impractical. ${ }^{7}$

Similarly, Daniel Chirot and Clark McCauley argue that, for elite perpetrators, mass murder is the "cheapest" way to overcome resistance to policies favored by the perpetrators or simply to dispose of groups that are perceived to be "in the way" of the realization of desired policies. Chirot and McCauley suggest that indigenous populations are most often the targets of genocide based on these kinds of strategic 
calculations because their presence on a given piece of territory is "troublesome," decreasing the strategic and/or economic value of that territory. When elite perpetrators calculate that the population "cannot be controlled or dispersed," genocide becomes the policy option. ${ }^{8}$ In the Killing Trap, Midlarsky also links the strategic choice to commit genocide to policy failure, but he suggests that genocide is a response to external, particularly territorial, losses. For Midlarsky, genocide is motivated by elite decision makers' desire for "loss compensation."

Whether one accepts a strategic actor explanation (particularly of the Valentino variety) as a useful basis for explanation and comparison hinges in part on one's position concerning the status of genocide as a means to an end or as an end in itself. Scholars who see genocide as a policy goal in and of itself will be at odds with the foundational premises of this approach, but those who take the opposite view may find it useful for understanding how and under what circumstances political elites make the policy choice to exterminate groups of people. As a broadly comparative theory of genocide in general, however, a strictly elite decision-making model leaves out the crucial role played by societal actors in the total process of destruction. If it takes a village to raise a child, it takes the state and society to perpetrate a genocide.

\section{Frontline killers}

In taking up the actors missing from elite-centered approaches, other genocide scholars who adopt an agency-centered approach have attempted to explain the behavior of the state and societal actors who actually carry out the order to commit genocide. Here the focus is still on explaining how human agency drives the genocidal process, not in terms of why the decision is made to pursue genocidal policies but in terms of how ordinary people can follow the brutal orders of their political and military superiors and slaughter their fellow human beings in great numbers.

Early attempts at this kind of explanation by psychologists and social psychologists assumed that the low-level perpetrators of genocide and other atrocities were outside the psychological norm because their actions were so beyond the pale of "normal" human experience. Theodor Adorno and his colleagues, for example, tried to identify among Nazi perpetrators a specific "authoritarian personality" that allowed these individuals to carry out genocidal policies. ${ }^{9}$ But research into individual and group responses to authority and organizational structures, including the infamous Zimbardo prison experiments at Stanford University, as well as later social psychological research based in part on these experiments and on other research, has determined that genocidal killing is perpetrated by quite ordinary people. One of the first scholars to make this profoundly disturbing observation, historian Christopher Browning, demonstrates in Ordinary Men: Reserve Police Battalion 101 and the Final Solution in Poland that the low-level perpetrators in this specific case were neither psychologically extraordinary nor highly ideological or fanatical believers in Nazi racial policies. Recent works by Chirot and McCauley, James Waller, and Alex Alvarez confirm Browning's observations through their respective explorations of the role of normal human psychology under extreme conditions and within particular military/security and bureaucratic organizational contexts. ${ }^{10}$

Chirot and McCauley's work concentrates on the central role of psychological needs, goals, and emotions in motivating not only elites but, more importantly, ordinary people to become killers. "Political killing," as Chirot and McCauley call it, is motivated by four often mutually reinforcing motivations. The first motivation, convenience, is in fact a strategic motivation that involves the same strategic 
calculation made by elites, as noted above, to simply "get rid of" groups that are in the way. The remaining three-revenge, "simple" fear (including fear of retribution by the victim group and fear of extermination), and fear of pollution-are psychological motivations that elites may feel but which they also manipulate in society at large. ${ }^{11}$ The "psychological foundations" for ordinary people's actual participation in mass killing lie in the confluence of a separate set of human emotions (again, often manipulated by elites), appeals to a "sense of duty," and the routinization of killing, training, "and good organization" 12 that foster obedience and provide incentives that "undermine personal responsibility."13 Chirot and McCauley cite some very basic human emotions in their explanation, including fear, anger, love, hate, shame, and humiliation, although they suggest that fear is the "key emotion for understanding genocide." 14 The authors also include in their explanation the human tendency toward what they call "essentializing others" and "double essentializing," described as a "battle of good and evil, of two incompatible essences in which love of the good [one's own group] means necessarily hate for the threatening out-group."15

What Waller calls his "four-pronged" process model of "extraordinary human evil" concentrates on the psychological and organizational contextual foundations of individual and collective behavior. Underpinning human behavior (extraordinarily evil or otherwise) is the first prong, our "ancestral shadow" that shapes our responses to authority (ethnocentrism, xenophobia, and the desire for social dominance) and is held in common by all human beings across time and space. The second prong identifies three forces that "mold the identity" of frontline killers: cultural belief systems that determine how one evaluates "controlling influences on one's life," "moral disengagement of the perpetrator from [the] victim" (facilitated by the use of moral justifications, euphemism, and "exonerating comparisons"), and individual rational self-interest. The third prong concentrates on the "immediate social context of the culture of cruelty" and how this influences the way individuals "think, feel, and behave." Here Waller cites three central factors: the role of professional socialization into military and security organizations, the binding factors of the group that "reinforce commitment to the group and its activities," and the "merger of role and person," that is, how "evil-doing organizations change the people within them." Finally, Waller's fourth prong, to be considered later, deals with the construction of the collective identity of the victim group, a process that leads to the "social death" of the victims. ${ }^{16}$

Drawing on criminological approaches to explaining youth delinquency, Alvarez disputes the idea that humans are naturally aggressive and prone to violence. For Alvarez, the real question is not "Why do they kill?" but "How do ordinary people overcome internalized norms against violence and become the executioners of genocidal regimes?" Alvarez argues that, like delinquent youths, low-level perpetrators defer, repress, or neglect personal beliefs and feelings ${ }^{17}$ so that their actions are reframed as acceptable to themselves and others through several "neutralization" techniques. These techniques include "denial of responsibility," in which the perpetrator claims that he or she was following orders or was otherwise coerced into killing and, therefore, does not bear responsibility for killing; "denial of injury" through the use of euphemistic language that cognitively sanitizes killing and brutality as "special treatment," "purification," "cleansing," and the like; "denial of [the] victim" such that killing becomes an act of self-defense against a threatening enemy and not the wanton destruction of innocent and defenseless men, women, and children; "condemning the condemners," whereby the perpetrator attempts to 
neutralize external criticism by arguing that similar acts have been perpetrated throughout history, even by the critics themselves; "appeals to higher loyalties" that characterize genocidal killing as a distasteful but necessary activity carried out not for personal gain, or based on personal motives, but for the greater good of the nation, race, or revolution; and "denial of humanity" through the dehumanization of the victim group and the deliberate creation of conditions of life that turn the victims into little more than animals, thus confirming the perpetrator's conception of the victims as subhuman. ${ }^{18}$

The great strength of Waller's analysis is his careful attention to the results of individual and social psychological research, which he uses to great effect to debunk any notion that, at least with respect to adult perpetrators, genocidal killers are psychologically abnormal or that their actions can be explained by the effects of indoctrination (i.e., "brainwashing") or socialization (e.g., Daniel Goldhagen's notion of a particularistic "eliminationist" anti-Semitism in Germany). Waller, Chirot and McCauley, and Alvarez ${ }^{19}$ also all effectively spell out the complex interrelationship between human agency based on psychological characteristics and emotions, on the one hand, and the influence of organizational structures, particularly military and bureaucratic organizations, on the other. Although human psychology is key to Waller's and Chirot and McCauley's explanations and remains ontologically prior, these authors, particularly Waller, carefully demonstrate that institutional structures shape and reshape, sometimes permanently, human behavior under extreme conditions. Where Waller's argument is less convincing is in his insistence that there is a hard-and-fast human nature shared by all human beings, regardless of culture, historical experiences, and the like. The evidence he presents to substantiate this point involves a high degree of inference from rather sketchy theories of early human development. The inferences he draws from these theories may not be warranted, since theories on their own do not constitute evidence. Moreover, Waller's references to experimental research on human subjects seems to confirm his main theses, but the research to which he refers involves, as far as the reader can tell, adult subjects only. With the advent of the Khmer Rouge in Cambodia, the Interahamwe in Rwanda, and the use of child soldiers in a large number of atrocity-laden conflicts in parts of Africa and Asia, the perpetrators of what Waller calls "extraordinary human evil" are now often children and teenagers. Such young, vulnerable, and likely impressionable killers may in fact be motivated to kill by indoctrination, abuse, and alcohol and drug use inflicted on them by their adult masters. Further research is required to determine whether Waller's conclusions about adults hold for child perpetrators as well or whether the behavior of child perpetrators is explained by other exogenous factors.

Like Waller's, Chirot and McCauley's model is rich in variables and, to a greater extent than Waller, these authors include references to a wide variety of cases of genocide to substantiate their claims. Leaving aside criticisms that could be leveled based on Chirot and McCauley's and Waller's use of broad dependent variables such as "political killing" and "extraordinary human evil" instead of the narrower variable of genocide, Chirot and McCauley's reliance on such a large number of independent and intervening variables and their use of mostly emotive variables makes comparative testing of their claims somewhat problematic. Since we are dealing with human emotions such as anger, hate, love, and revenge, it is not clear how one is to go about operationalizing these emotions into variables that can actually be measured and compared across cases, in stable comparisons by which the researcher can be confident 
that he or she is measuring and comparing the same thing. How does one measure human emotions, particularly in historical cases? The authors do not give us much methodological guidance, and their very general and often brief references to historical case studies similarly does not show us in a convincing way how emotions of the kind they believe are significant can accurately be gleaned from historical sources. Surveyand interview-based research into perpetrator behavior in more recent cases of genocide may be a preferable way to tap the variables the authors find important, but, again, this kind of research would have to include an extended discussion of how the survey was constructed in order to accurately measure the existence and the precise effect of the emotional variable(s) under investigation.

Further, because emotions like anger, hate, fear, and revenge are commonly held by ordinary people and are often manipulated for instrumental reasons by political and other elites, under all sorts of circumstances and for all sorts of different reasons, one can question whether the explanation of political killing offered by Chirot and McCauley might also just as effectively explain other phenomena, such as terrorism, civil war, or ethnic conflict. To develop a comparative theory of genocide, we need to highlight the variables that lead specifically to genocide and not to other dependent variables.

\section{Society}

Agency-centered approaches also focus on a third collective actor in genocide-society, namely the role ordinary people play as bystanders who, through their acquiescence or tacit consent, allow genocide to happen. Early attempts to explain societal behavior argued that societies that have gone on to experience genocide are psychologically predisposed toward the victimization of specific marginal groups. Such predispositions are said to be linked to aspects of early childhood development such as authoritarian parenting or to commonly held psychological characteristics in what some analysts have labeled "national character." 20 Rejecting the assertion that certain societies have the same psychological make-up or are socialized into exactly the same cognitive orientation toward a specific victim group, Ervin Staub compares different societies in which genocide has occurred and suggests that many members of societies that experience genocide become psychologically distressed as a result of severe crises and are therefore willing to accept the victimization of marginal groups. These same societies also have a history of antipathetic relationships with what are perceived to be marginal groups. Once crises take hold, members of the society project their own frustrations and hardships onto these groups. Crises are perceived by ordinary people as events that create "winners" and "losers"; marginal groups are identified as the "winners," while the members of the majority group see themselves as the "losers" who are suffering at the hands of a distrusted minority. As crises deepen, and as the state begins to use repression and violence against the victim group, the wider society gradually becomes psychologically disposed to accept the victimization of the group and, in the case of some individuals, ripe for recruitment into the genocidal process as low-level killers. ${ }^{21}$

By employing an explicitly comparative approach, Staub avoids the central problem of the Goldhagen study: the labeling of specific societies and specific groups of people as "natural born killers," so to speak. Staub is more interested in the general conditions under which ordinary people are willing to accept the perpetration of genocidal violence against members of their own society and in the social psychological orientation toward the victim group that is required for a population to become 
bystanders to genocide. But, like that of Chirot and McCauley, Staub's work lacks explicitly stated methodological guidelines that would leave the reader confident that his research, which-again like Chirot and McCauley's-is quite general in many cases, is based on the operationalization and comparison of equivalent variables and sound inferences.

In sum, agency-oriented approaches, mostly focused on psychology, offered by scholars in recent years give us a foundation upon which we can try to understand and explain elite, individual, and societal behavior in genocide. But they cannot account for what the structural explanations give us-the macro cultural, social, economic, political, security, and ideational contexts that also shape genocidal policies and behaviors.

\section{Structural Approaches}

\section{Culture}

Culture can be seen as a necessary but not sufficient condition to explain genocide. Cited by some scholars as an important background condition, culture is regarded, depending on the author, as either a macro- or a micro-level variable. While culture is an important variable, its use in explaining genocide is fraught with difficulties, both because culture is hard to define and measure and because of the problem of overgeneralization, particularly at the macro level when the culture variable concerns the culture of a whole society. Nonetheless, the idea of trying to find which long-standing beliefs, norms, attitudes, and practices underpin genocide continues to be an attractive, if partial, approach in the literature.

At the macro level, perhaps the most ambitious and controversial use of the culture variable is that of Daniel Goldhagen in Hitler's Willing Executioners. In this book Goldhagen attributes the Nazi genocide of European Jews to the thorough cultural indoctrination of Germans into what he calls "eliminationist anti-Semitism."22 Goldhagen's thesis is a study in what can go wrong in an overly simplistic culturebased argument, namely the uncritical assertion, backed by insufficient or distorted evidence, that all Germans were socialized or indoctrinated into exactly the same form of anti-Semitism and that the eliminationist anti-Semitism of Germany was unique to that country and its people. Goldhagen's analysis has been widely criticized on a number of grounds, not the least of which is his tendency to essentialize the identity of the perpetrators.

A much more effective use of culture is Alex Hinton's examination of the importance of local cultural influences on how low-level perpetrators in Cambodia were able to turn with such brutality against not only the country's ethnic minorities but other Khmers from the cities and inward against suspect cadres within the Khmer Rouge itself. ${ }^{23}$ Hinton shows that the Khmer Rouge leadership was able to skillfully employ culturally salient language and appeal to cultural practices to motivate ordinary Khmers to commit genocidal violence. He argues, for example, that one enduring cultural practice called kum-a long-standing grudge as a result of real injury or a public loss of face-has often led historically to the meting out of karsangsoek, or "disproportionate revenge." ${ }^{4}$ Hinton suggests that the cultural model of disproportionate revenge is a "form of knowledge which most Cambodians have internalized and may be inclined to enact in given circumstances"- usually in the aftermath of individual or collective injury or loss of face. The "cultural knowledge" of disproportionate revenge "constitutes a crucial site upon which genocidal regimes 
can work," with perpetrator elites "us[ing] these highly salient cultural models to motivate individuals to commit violent atrocities." 25

The importance of local culture and genocidal violence has also been noted by Christopher C. Taylor in his examination of mass participation in the Rwandan Genocide. For Taylor, the perpetrators in Rwanda conceptualized the victim group, and the threat they were believed to pose to the Hutu majority, along culturally specific lines that referred to commonly held beliefs in the deleterious effects of "obstructions" in the body that interrupted the proper "flow" of bodily fluids. The Tutsis were characterized, according to Taylor, as "sacrificial victims" in a "mass ritual purification, a ritual intended to purge the nation of obstructing beings." This conceptualization of the threat posed by the victim group was "imagined through a Rwandan ontology that situates the body politic in analogical relations to the individual human body." 26 These culturally specific reference points not only motivated the killing but informed the manner in which the killing was manifested in the Rwandan case, which included dumping victims (dead or alive) into latrines or rivers.

From a historical perspective, Omer Bartov also calls for a detailed examination of local contexts so that we can understand "much of the reality of genocide" that occurs at the local level, including "the interaction between friends and neighbors" and "encounters with reception of forces [tasked with committing the genocide] arriving from outside the community." Bartov continues that "the conduct of the community is often crucial to the success or failure of state-organized genocide in a given area." ${ }^{27} \mathrm{Jan}$ Gross's study of the destruction of almost the entire Jewish community in the Polish village of Jedwabne by their non-Jewish neighbors on a single day of bloodletting in 1941 is a leading example of this kind of micro-level history. ${ }^{28}$

Although Hinton's, Taylor's, and Gross's studies are ideographic examinations of the role of culture, appeals to culturally significant language and practices, and local historical contexts in three specific cases, we need not rule out the search for cultural or local comparisons across cases. Such comparisons can be made at the societal or the local level, provided that attention is paid to establishing with sufficient evidence the relationship between cultural beliefs and practices, on the one hand, and genocidal behavior, on the other, both within and across cases, and that equivalent (not identical) beliefs and practices can be found in other cases upon which we can base reliable comparisons.

One way to further develop comparative cultural approaches at the macro level is to focus on the role of political culture specifically as a precursor to genocide. Two dimensions of the pre-genocide political culture lay the ideational foundation for later genocidal policies: beliefs and attitudes concerning membership in the political community and elite political cultural perceptions of the meaning of conflicts in society and the state's response to conflict. The first, purely attitudinal, dimension taps how members of the dominant society and political elites conceptualize membership in the political community. Societies that have historically maintained a restrictive conception of who constitutes "genuine" or "authentic" membership, even in the face of formal legal recognition of membership, may be more likely (though by no means certain) to commit genocide against "inauthentic" marginalized members who are later redefined as completely alien and a serious threat to the survival of the community. The second dimension shifts the analysis toward an examination of historical elite conceptualizations of real and perceived conflicts, either within society or within the state, as zero-sum struggles that cannot be solved through 
dialogue or compromise but only through the exercise of state power, possibly including the use of force.

In sum, although cultural explanations of this or any other kind fill in part of the genocidal puzzle, they cannot, on their own, explain why genocide happens. Values, beliefs, norms, and practices at the macro and micro levels can, under the right conditions (see the discussion of crisis below), set the stage for genocide and, once the killing begins, shape the course and character of the genocidal process at the state, societal, and local levels.

\section{Divided societies}

Another structural approach found in the literature suggests that societies riven by ethnic, religious, socioeconomic, or other cleavages are particularly vulnerable to genocide. One of the first comparative genocide scholars, Leo Kuper, took the prior existence of what he labeled "plural societies" as the "structural base for genocide." 29 As a necessary condition, but one that does not make genocide inevitable, Kuper argued that plural societies in which cleavages are particularly "persistent and pervasive" are more likely to experience genocide, especially when political or economic inequality is "superimposed" on ethnic, religious, racial, or socioeconomic "differentiation." This kind of social structure, in turn, "aggregate[s] the population into distinctive sections, thereby facilitating crimes against collectivities. The divisions being so pervasive, and relatively consistent in so many spheres, issues of conflict may move rapidly from one sector to another, until almost the entire society is polarized."30 Applying a similar argument to the Armenian Genocide, Richard Hovanissian argues that the existence of a plural society "with clearly defined racial, religious, and cultural differences" in Ottoman Turkey was one of the preconditions for the genocide of $1915 .^{31}$ Kuper cautions, however, that simply because a society is characterized by moderate or even extreme pluralism, it does not follow that it will automatically fall victim to genocidal violence. Genocide is unlikely if a plural society does not experience "the subjective reactions and opportunities to sustain a destructive conflict" that mark genocidal violence. ${ }^{32}$

Hinton argues that societies that go on to experience genocide are marked by severe "social divisions" that arise because of "segregation and differential legal, sociocultural, political, educational, and economic opportunities afforded to social groups." 33 Helen Fein also notes that societies that are marked by "ethnic stratification" are more likely to be predisposed to ethnic, racial, or religiously based genocides $^{34}$ but that political revolutionary or anti-revolutionary genocides, such as those in Cambodia or in Indonesia during Suharto's attack on the Indonesian Communist Party in 1965, are the product of other factors (legitimacy problems, moral exclusion, blaming the victim, "tolerance" of an international patron for a regime's genocidal policies, social unrest due to economic conditions, and the onset of war). ${ }^{35}$

Critics of the "divided society" approach contend that large- $N$, mostly quantitative empirical evidence shows that not all plural societies go genocidal and that some societies that do experience genocide, such as Cambodia's, are not characterized by deep ethnic, religious, or socioeconomic cleavages. ${ }^{36}$ While the first observation is accurate, scholars who cite societal cleavages as an important variable do not argue that such cleavages directly cause genocide, or that they do so alone. Rather, such divisions create the potential for genocidal violence, but only in concert with other intervening variables such as severe destabilizing crises or radical eliminationist ideologies espoused by equally radical genocidal elites. 
No matter what the source of societal cleavages, the important contribution of this approach is the recognition that divided societies are fragmented societies in which there is a relative lack of solidarity, trust, and, sometimes, tolerance between groups. ${ }^{37}$ Just as political scientist Robert Putnam feared for the health of American democracy because Americans were "bowling alone," genocidal societies are often (but not always) societies whose members tend to "bowl with their own kind." Genocidal elites skillfully play on and exploit these divisions, while groups within society are unable or unwilling to rally together to resist such entreaties and to protect targeted members of their own community.

\section{Crises, revolution, and war}

The fact that serious political, economic, or security crises have frequently preceded genocide, at least in the modern era, has not been lost on many genocide scholars. While it is recognized in the literature that most societies that endure destabilizing crises of one kind or another do not go on to perpetrate genocide, there is a strong sense among some genocide scholars that there is a connection between crises, revolutionary upheavals, warfare, and genocide.

In her pioneering work Accounting for Genocide, Helen Fein lists reduction of a state's "rank" as a consequence of defeat in war or of internal strife as one of several "predisposing conditions" that can propel a state toward a "crisis of national identity" in which elites become more likely to "adopt a new political formula to justify the nation's domination and/or expansion" as well as "idealizing the singular rights of the dominant group." 38 For Fein, crises, and elite responses to them, do not directly cause genocide; rather, crises are part of a longer process that can, under certain circumstances, culminate in genocide. In his analysis of elite responses to crises, Midlarsky argues that political elites make the strategic decision to commit genocide in the face of a loss of territory and other external security crises as a form of "loss compensation." 39 Approaching the effects of crises in a more general way, Florence Mazian identifies in another early work in the field the role of "internal strife" as a "social condition" that may contribute to the "value added process" that results in genocide, since internal strife_-including "real or threatened deprivations," various economic shocks, real or imagined or anticipated frustration, and what Mazian calls "normative upheavals" such as rapid social and institutional change or modernization-can "heighten social cleavages such as ethnic, political, class, and religious divisions." 40 With respect to ordinary members of society, Staub suggests that crises create psychologically "difficult life conditions" that induce feelings of distress and frustration, which are then projected onto a marginalized group, particularly any such group that has recently enjoyed a greater degree of socioeconomic success. ${ }^{41}$ For Hinton, crises create a "hot" and "volatile" context in which genocidal processes are more likely to be "set off." Socioeconomic, political, and security upheavals produce "anxiety, hunger, a loss of meaning, the break-down of existing social mechanisms," and often presage a "struggle for power." 42 Barbara Harff's large multi-case quantitative analysis of genocides and politicides since 1955 confirms that political upheaval and a prior history of genocide or politicide are strongly predictive of similar atrocities. $^{43}$

Conceptualizing crises as opportunities that are seized by elite actors, Chirot and McCauley suggest that crises create the conditions under which genocide and mass killing are more likely to occur. A crisis is a disruptive event during which moral inhibitions against killing are loosened, especially when political elites manipulate 
the crisis. As such, crises give rise to "the potential for mass killing" that can quickly reach "genocidal proportions." 44 In this argument, elite responses to crises are largely instrumental, in that crises are opportunities that elites grab to mobilize support for their own destructive policies. Another crisis-as-opportunity argument suggests that crises allow radical political elites both to come to power and to implement previously developed genocidal policies against a target group. In this case crises are what Sidney Tarrow calls, in another context, a "political opportunity structure." 45 Lucy Dawidowicz's “intentionalist" thesis that Hitler's Nazis developed their plan to exterminate European Jewry during the turbulent interwar years before their rise to power, used the upheavals of that period to come to power, and initiated a continentwide war to realize their pre-existing genocidal policies stands as a prime example of a political opportunity approach. ${ }^{46}$

We can see, then, that authors who link crises to genocide do not generally suggest that destabilizing crises necessarily lead to genocide. Rather, crises are conceptualized as an intervening variable, as a precursor that acts as a trigger for genocide. What is important about crises is not so much the specific nature of the crises themselves but how they are perceived by ordinary people and elites: Why did they happened, who is to blame, and, most importantly, how can the state and society be protected from similar events in the future? To borrow Alexander Wendt's phrase about anarchy in the international system, crisis is what elites and society "make of it." ${ }^{4}$ What elites and society "make" of crises rests, at least to some degree, on prevailing cleavages, attitudes, beliefs, and practices. In genocidal situations, crises are interpreted as illustrating an ongoing struggle between the political community, on the one hand, and a specific group, on the other. This group is seen to be responsible for the current situation and to benefit from it. Taken together, crises and elite (and popular) reactions to them serve to animate the more virulent anti-group features of the pregenocide political cultural norms, attitudes, and practices, turning what were hitherto relatively benign manifestations of exclusionary beliefs and authoritarian political practices into an extremist construction of the identity, interests, and potential actions of the target group. This reconstruction of the victim group culminates in the formation and implementation of genocidal policies designed to bring about the physical or biological destruction of the target group.

Opportunities for genocide can also arise in the form of revolutions. While noting the central importance of revolutionary ideology (see below) and political myth in explaining genocide, Robert Melson also argues that a key structural condition for the revolutionary recasting of society and the "total domestic genocides" that resulted in Ottoman Turkey, Bolshevik Russia, Nazi Germany, and Khmer Rouge Cambodia was the collapse of the old regimes and their fragile successors-the collapse not only of the state's political institutions but also of its legitimacy. Key crises for Melson are military defeat and domestic political and economic upheavals. ${ }^{48}$

In a more recent book, however, Edward Kissi notes that not all revolutions give way to genocide and that while revolution turned genocidal in Cambodia, it did not in socialist revolutionary Ethiopia. In Kissi's view, revolutions turn genocidal only under very specific conditions: when the targets of mass political killing are fragmented and atomized to such an extent that they cannot defend themselves against an aggressive state; when the state is able to successfully dominate society; and when the state targets for liquidation ethnic, religious, socioeconomic, and inactive or already defeated political groups, not political groups that genuinely and actively resist a revolutionary regime. In Ethiopia, which Kissi believes experienced "politicide" 
(as defined by Barbara Harff) and not genocide, revolution gave way to severe repression, political violence, and terror directed at the many armed opposition groups (but not at ethnic or religious groups) and their supporters. ${ }^{49}$

Wars, as other scholars have argued, can also act as a structural condition that can lead to, and facilitate, the perpetration of genocidal violence. Eric Markusen and David Kopf, for example, have argued that while total war and genocide are not identical phenomena, they nonetheless share a number of characteristics. Total wars and genocides are pursued by political elites to protect national security, are underpinned by ideologies that dehumanize the targets of violence, are bureaucratically organized, and are perpetrated with sophisticated technologies that kill large numbers of people easily and efficiently in a manner that insulates the killers from the suffering of their victims. ${ }^{50}$ Aside from these commonalities, Markusen and Kopf also suggest that war, as a form of extreme security crisis, creates social and psychological conditions "conducive to the outbreak of genocide and genocidal killing." By exposing societies to severe crises and threats to national survival, wars

create the potential for pre-existing inter-group tensions in a culturally or racially diverse society to flare into violence directed by the majority against members of a minority group. The threat of disruption is not only blamed on the external enemy but can also be directed at members of a minority group within the society. ${ }^{51}$

Further, war can give governments the tools to commit genocide and to cover its tracks. Markusen and Kopf thus note that governments engaged in total war "tend to become more centralized, secret, and powerful" and tend to use dehumanizing propaganda to vilify their enemies. "The result can be diminished popular awareness of, and resistance to, ruthless governmental actions against both external and internal enemies." ${ }^{2}$ Governments at war also have at their disposal combat-ready soldiers in the field who can be diverted to perpetrate genocide. Meanwhile, the conditions of war leave victim groups isolated and vulnerable and perpetrators and bystanders psychologically desensitized to violence as a result of their exposure to the violence of war. ${ }^{53}$ Similarly, Scott Straus argues that in Rwanda the renewed civil war in 1994 helped drive the genocide because the war was constructed by the perpetrators as a security crisis in which violence had to be used to overcome a threat; all Tutsis were constructed as "enemies" along with the Rwandan Patriotic Front. The civil war also created a circumstance of uncertainty and insecurity within which mass violence was legitimized and "specialists in violence" such as soldiers, gendarmes, and militias could be mobilized for genocidal killing. ${ }^{54}$

Omer Bartov, focusing on the construction of the meaning of war, notes that defeat in war can lead not only to the search for, and punishment of, internal "enemies" responsible for the catastrophe but also to the conceptualization of combat in modern industrialized total war as a necessary and glorious form of destruction in which the "destruction of others" is believed to bring about one's own "resurrection." 55 In the German case, "the Great War's new fields of glory were the breeding ground of fascism and Nazism, of human degradation and extermination, and from them sprang the storm troops of dictatorships and the demagogues of racial purity and exclusion." ${ }^{" 56}$ When war came again on a much wider and more horrific scale, German soldiers

expressed pride and satisfaction in finally being able to destroy their enemies, be they soldiers, prisoners, civilians, or provoking the greatest glee, Jewish men, women, and children. It was at this point that massacre and glory became synonymous. ${ }^{57}$ 
For scholars like Markusen and Kopf, Kuper, and, more recently, Martin Shaw, war not only sets the stage, and acts as a cover, for genocide but can devolve into genocidal violence. Genocide, for Shaw, is in fact a distinctive form of war against civilians and is intertwined with other forms of war, particularly what he calls "degenerate war." Degenerate war involves "the deliberate and systematic extension of war against an organized armed enemy [what Shaw identifies as legitimate or "real war"] to war against a largely unarmed civilian population"58 in conflicts such as guerrilla wars, counter-insurgencies, or wars that involve the aerial bombardment of civilian populations. Although Shaw defines genocide as "the destruction by an organized armed force of a large unarmed civilian group (or groups)" in which civilians are regarded as enemies "in themselves" and not "through their relationship to an armed enemy," genocide, because of its "definition of civilian groups as enemies to be destroyed," utilizes the logic of war and is, therefore, an extension of degenerate war. Genocides are often perpetrated, Shaw notes, within the context of military (war) and political (revolutionary and counter-revolutionary) struggles and are frequently ended by war. ${ }^{59}$ War, and the preparation for it, can also help, in Shaw's view, to turn the corner from degenerate and other forms of war to genocide. Perpetrator states are often militarized states that have experienced war in the recent past and consequently have in place the military and paramilitary institutions and a militaristic ideology that legitimizes the use of military force against defined enemies. ${ }^{60}$ Because Shaw sees genocide as a form of war, he claims that genocides, wars, and revolutions are all forms of conflict defined by two commonly held characteristics: that "opposing sides aim to destroy each other's power" and that each side is "prepared to engage in mass killing of the enemy in order to achieve their goal." ${ }^{61}$ Like war, genocide is a form of conflict in which the perpetrator aims to "destroy" the "social power" (economic, cultural, and political power) of a group and their ability to fight back. ${ }^{62}$ While the conflict usually begins as an unequal struggle in which the victim group (a term Shaw conspicuously does not use) is initially unarmed, it evolves into a more balanced confrontation once the victims begin to resist and find more powerful domestic or international allies. Shaw offers the fact that wars fought by internal forces (e.g., the Rwandan Patriotic Front) or by external forces (e.g., the Allies in World War II) frequently end genocide as evidence of this position.

As the literature shows, revolution and war are the extremist contexts within which modern genocides are often perpetrated. But it would be a mistake to equate or conflate genocide with either. Both revolutions and wars occur without going genocidal; some genocides occur after a war is over (e.g., in Cambodia) or do not occur during warfare at all (e.g., the Stalinist purges of the 1930s-assuming, of course, that one classifies the latter as genocide). Shaw's contention that genocide is a form of war because "opposing sides aim to destroy each other's power" and each side is "prepared to engage in mass killing of the enemy in order to achieve their goal"63 conflates genocide with something it clearly is not: a contest between two opposing forces that possess the intention to defeat each other in a struggle over something concrete (economic, political, and cultural sources of "social power" as Shaw puts it) fought by two opponents with actually existing offensive and defensive power capabilities.

Part of the problem with Shaw's thesis is the confusion over the status of the perpetrators' and victims' intentions. The UN Convention on the Prevention and Punishment of the Crime of Genocide and many genocide scholars argue that genocide is defined by the "intent to destroy, in whole or in part" the victim group "as such."64 This is an intention that is held only by the perpetrators, not the victims, which is 
precisely why the two main collective actors in genocide are referred to not as "combatants" but as "victims" and "perpetrators." Physical and/or biological destruction of the members of the victim group is the policy goal of genocidal regimes, not simply the stripping of the group of it power capabilities, which could be accomplished by all sorts of other policies that fall short of genocide. On the other side of the ledger, confronting a regime as an opposing force bent on depriving the state of its power capabilities, possibly through resort to "mass killing," was not the intention of the Ottoman Armenians, European Jews, the various victims of the Khmer Rouge, or Rwandan Tutsis (save members of the Rwandan Patriotic Front).

As for the use and deployment of force by the victim group, the victims of genocide are victims of this particular crime precisely because of their helplessness and the lack of real (as opposed to perceived) threat and opposition they pose to the perpetrators. In her definition of genocide, Helen Fein tells us that genocide is a

sustained purposeful action by a perpetrator to physically destroy a collectivity directly or indirectly, through interdiction of the biological and social reproduction of group members, sustained regardless of the surrender or lack of threat offered by the victim. ${ }^{65}$

For Frank Chalk and Kurt Jonassohn, genocide is a "form of one-sided mass killing in which a state or other authority intends to destroy a group"; 66 Israel Charny, in what he calls his "generic" definition of genocide, similarly notes that genocide is characterized by the

mass killing of substantial numbers of human beings, when not in the course of military action against the military forces of an avowed enemy, under conditions of the essential defenselessness and helplessness of the victims. ${ }^{67}$

Whether we argue that genocide and war are distinct phenomena or that genocide is in fact a form of warfare, we must recognize that the victims of genocide are just that: victims who do not pose a real threat to their tormentors, who are not combatants in an equal or even an unequal contest with a state or other authority, and who do not possess actually existing power capabilities that they can deploy to defend themselves and fight their enemies. The fact that small numbers of victims may actively resist their destruction, sometimes through force of arms, neither transforms these people into regular combatants nor turns the attempted destruction of their own group by a predatory state into a two-sided conflict.

\section{Regime type}

Other structural explanations focus on how the structure of political regimes determines the adoption (or not) of genocidal policies. One of the earliest comparative explanations of genocide, offered by Irving Horowitz, argues that genocide is inherent to totalitarian political systems. Because totalitarian regimes attempt to exert total political, economic, and social control over all aspects of life and over all members of society, such regimes inexorably end up liquidating whole groups of people who are deemed to be outside of, or hostile to, the totalitarian order. ${ }^{68}$ Similarly, for Hannah Arendt (although her work predates Horowitz and does not deal explicitly with genocide but with totalitarianism) the fullest expression of totalitarianism-that practiced by the Nazi and Stalinist regimes-was the exercise of "total domination" in the death camps, in which "everything," including the extermination of superfluous peoples, became possible. ${ }^{69}$ 
The main weakness of the totalitarian regime thesis is that it is overly deterministic. As we will see below, although the ideologies that animate what have been labeled totalitarian regimes ${ }^{70}$ - namely, Communist regimes and Nazi Germany-were radical and highly exclusionary, not all totalitarian regimes have perpetrated genocide against segments of their own population. Pol Pot's Democratic Kampuchea certainly did so, but other so-called totalitarian regimes, such as unified socialist Vietnam, did not single out whole groups of people for destruction, although the first decade of Communist rule after Vietnam's unification in 1975 was marked by repression and serious human-rights abuses against elements of the former regime. Given the different experiences of totalitarian regimes in the twentieth century with respect to the perpetration, or not, of genocide, we cannot definitively argue that the structures and processes of totalitarianism invariably result in the genocidal killing of specific groups.

Looking at the opposite side of the political spectrum, Rudolph Rummel links regime type to genocide and other forms of mass violence by suggesting that while democratic regimes are liable to inflict violent death on citizens of other states through combat operations, bombings, or isolated atrocities, they are very unlikely to target their own citizens for mass repression or killing. Based on a detailed statistical examination of deaths caused by governments, Rummel argues, according to what he calls the "power principle," that

the more power a government has, the more it can act arbitrarily according to the whims and desires of the elite, and the more it will make war on others and murder its foreign and domestic subjects. The more constrained the power of governments, the less it will aggress on others. ${ }^{71}$

Taking Rummel's analysis further, Harff's statistical analysis shows that failed authoritarian states are three and a half times more likely to lead to genocide or politicide than state failure in democratic regimes. ${ }^{72}$

As Rummel's empirical investigation tells us, regime type, at least for twentiethcentury genocides, is related to whether a regime is more or less likely to commit genocide. Non-democratic regimes have a higher incidence of committing atrocities, including genocide, against their own people, than democratic regimes, which in the past century have not perpetrated genocides against their own people. But because there is also a large number of authoritarian regimes, historical and current, that have not perpetrated genocide, Rummel's study tells us only that there is a correlation between authoritarian regimes and genocidal policies, not that there is a causal connection between the two phenomena. The most we can say, then, is that nondemocratic states are more likely than democracies to commit genocide. This is so not simply because a state is authoritarian but because states that go on to commit genocide historically have used authoritarian methods, such as repression and sometimes violence, to manage domestic conflicts and confront real and perceived enemies. Elites' strategy of habitually using confrontational or violent methods of conflict management is underpinned by a long-standing elite political culture that frames conflicts as zero-sum struggles in which the state must win or be completely defeated. ${ }^{73}$ This history of authoritarian practices and perceptions, in turn, creates an ideational and experiential context that sets the stage, during genocide, for the targets of destruction to be perceived as a mortal threat by elites. Following historical and political cultural precedent, the victims are dealt with not through concessions or lesser forms of repression but through violent processes of extermination intended to secure the survival of the state and the majority society. 


\section{Modernity, the modern state, and modern exclusionary ideologies}

The final group of structural arguments links the onset of genocide to broad processes of modernization, particularly the rise of the modern bureaucratized nation-state, as well as to the creation of radical exclusionary nationalist, racist, or revolutionary ideologies. The former argument suggests that it is the material structure of the modern nation-state that facilitates genocide, while the latter argument concentrates on ideology as an ideational structure that produces genocidal behavior.

Zygmunt Bauman argues in his analysis of the structural foundations of the Holocaust that the increased division and specialization of bureaucratic functions within the modern nation-state and society allows the thousands of people involved in genocidal programs to remove themselves conceptually from any moral responsibility for their small and specialized part in the extermination process. ${ }^{74}$ Thus the killing of whole groups of innocent human beings has become conceptually, psychologically, and morally unproblematic in the modern age.

Influenced by modern conceptions of inferior and superior races or exploited and exploiting classes, coupled with a proclivity for powerful, centralized, bureaucratic states to conceive of grand projects of social engineering and their capacity to implement such policies, modern states have the potential to become genocidal "gardener states," according to Bauman. For the gardener state, genocide is not a policy of destruction but a grand project of construction. Recalling Arendt's totalitarian everything-is-possible thesis, Bauman argues that the gardener state seeks to construct new social, economic, demographic, or political orders as a landscaper plants and tends a garden. Just as gardens inevitably grow weeds that do not belong in a meticulously designed garden, so new racial, national, or revolutionary systems contain human beings who do not belong in the new order. As weeds are pulled by a gardener to maintain the intended design and composition of the garden, groups of human beings who do not belong to the new order must be exterminated by the gardener state. ${ }^{75}$

Although Bauman offers a compelling metaphor congruent with the spirit of many radical ideologies and genocidal elites' desire to construct completely new societies, his analysis does not tell us why the pulling of human weeds-that is, the removal of certain groups who do not belong to the new order-necessarily involves physical extermination. Simply understanding a group as misfits who upset the composition of the new order cannot explain why genocide becomes a policy option for some elites, rather than apartheid-like segregation and repression, internal deportation, or expulsion. The latter policies accomplish exactly what Bauman suggests the gardener state wants to do: the removal of groups of people who are thought to deviate in some way from the rest of the newly constructed order. His metaphor is not irrelevant, but it is too benign. We must remember why gardeners get rid of the weeds in their gardens. It is not just because weeds do not look right, or were not in the flat of flowers the gardener planted; it is because, if left unchecked, they will choke off and kill the garden. That is why gardeners do not just pull off the tops of weeds, or replant them somewhere else, but instead are careful to thoroughly dig weeds out by their roots or use herbicide to ensure that the weeds can never grow again.

Alvarez also focuses on the role of the state and state institutions as the principal perpetrators of genocide, but without explicitly linking this role to the consequences of modernity itself. For Alvarez, genocide is a form of "state criminality" that is underpinned by two "constructs of belief," sovereignty and nationalism. ${ }^{76}$ Because sovereignty rests on the principle of non-interference by states in the domestic affairs 
of other states, and because there is no higher authority in the international system above and beyond the state, states encounter few, if any, restrictions on their domestic policies and are unlikely to be faced with intervention by other states. ${ }^{77}$ Nationalism, meanwhile, is the ideological mechanism that "assures loyalty to and belief in the state." ${ }^{78}$ Alvarez acknowledges that nationalism exists in a variety of forms and that it is the most extreme forms of ethnic nationalism, particularly in multiethnic states, that fuel state-sponsored genocide. Citing Michael Ignatieff, he contends that ethnic nationalism "exacerbates perceived differences among people, and transforms

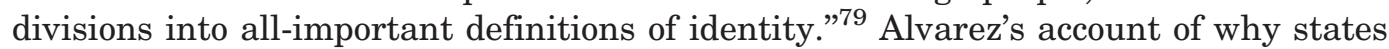
perpetrate genocide extends beyond these two foundational conceptions, however, to include the connection between genocide and war (in a manner similar to that discussed above) and the law, which he identifies as a "set of resources" that the state mobilizes and uses as a tool to translate its power into genocidal policies. ${ }^{80}$ Expanding on Bauman's analysis, Alvarez also discusses in detail the role of state institutions, both military/security and civilian bureaucratic, in the perpetration of genocide. For Alvarez, state institutions are perpetrators of genocide, because their role is to implement specific genocidal policies. Once genocide begins, the members of these institutions engage in criminal activity (i.e., genocide) not as individuals but as members of what have essentially become criminal organizations. Members of military, paramilitary, and state security organizations perpetrate genocidal killing because "their training is geared toward providing recruits with the technical skills of violence and socializing them into a value system that supports fierceness, aggression, and solidarity with their comrades." 81 Civilian state bureaucracies, with their emphasis on technical efficiency, depersonalization, and the strict application of rules and procedures, produce desk killers who faithfully apply the "rules" of genocide to unseen depersonalized "units" without having to think about or witness the very real consequences of their small, often specialized, but entirely lethal actions. ${ }^{82}$

Bauman's and Alvarez's insights into bureaucratic specialization and the moral distancing of perpetrators from the genocidal process do help explain how it was that large numbers of public and private employees, managers, and administrators in Nazi Germany could continue to play their own small but deadly parts in keeping the machinery of destruction in motion, unmolested by moral qualms about the program's outcome. This kind of argument, however, cannot explain other genocides, such as those in Cambodia and Rwanda, where the killing was not bureaucratized but instead involved face-to-face public killing, albeit directed by the state, ${ }^{83}$ sometimes by ordinary people who were not members of a state security organization. Nor can the modern bureaucratic state thesis explain why political elites decide to perpetrate genocide in the first place, only how it was that a modern Western state like Nazi Germany, with desks full of killers like Adolf Eichmann, had the capacity to execute genocidal policies.

Other genocide scholars suggest that the main product of modernity that has produced the genocides of the twentieth century and beyond is not the modern state itself but modern revolutionary ideologies that are inherently genocidal. ${ }^{84}$ These ideologies rest, Eric Weitz argues, on modern conceptions of the world as naturally divided into races and nations, or on Marxist notions of class conflict between exploiting and exploited classes, ${ }^{85}$ or, as Hinton contends, on a more general turn toward an "emphasis on the individual, empiricism, secularism, rationality, progress," and the potential of science. For Hinton, the latter can produce genocidal processes of social engineering in which "human societies, like nature, could be mastered, 
reconstructed, and improved." ${ }^{\prime 86}$ In modern societies, our innate capacity to identify differences between peoples becomes "reified" in a world in which modern nationstates "covet homogeneity." Modernity also gives rise to the crafting of hierarchical scientific typologies that identify groups as inherently inferior or superior, to the use of science as the "legitimating rationale for slavery, exploitation, and ultimately genocide," and to conceptions of progress that are used as a standard against which peoples are judged or can be manipulated or even exterminated "to achieve [a] desired end." 87

In his account of twentieth-century genocides, Weitz concentrates specifically on the evolution of, and appropriation into, radical eliminationist ideologies of a number of specifically modern concepts. Influenced by Johann Gottlieb Fichte's and Johann Gottfried von Herder's conception of nations as primordial entities with a common language, culture, and history, nationalism by the nineteenth century, according to Weitz, morphed into a racialized understanding of nationhood as an ethnic and racial community and not simply a locus of political rights. ${ }^{88}$ Primordial and exclusionary understandings of race and nation gained particular prominence in Germany and elsewhere on the European continent by the latter half of the nineteenth century. Weitz further argues that the rise of race thinking and ethnic nationalism coincided with the rapid expansion of European imperialism and the resulting exposure of increasing numbers of Westerners to indigenous and other peoples who were physiologically and culturally different from themselves. These encounters only seemed to confirm the idea that some races, namely white Europeans, were superior to others, namely Africans, Asians, and the indigenous peoples of the Americas already colonized by European settlers in previous centuries. ${ }^{89}$ The felling of Western colonists by tropical diseases and the simultaneous rise in support for eugenics and the "theory" of social Darwinism (the struggle for the survival of the fittest races) culminated in a conception of society as

analogous to the body and race as a biological organism, whose health needed constant attention, whose vitality was continually in danger of being sapped by killer bacteria borne by the weaker members and by those of completely alien races. ${ }^{90}$

When added to the dehumanization of the enemy during World War I, all of these ideational factors produced, according to Weitz in the case of the Holocaust, the idea that the Jewish "disease" in Germany weakened the German "body" and should be removed through radical eugenicist measures in order to preserve the racial purity of Aryans. ${ }^{91}$ Similar revolutionary ideas that societies are divided based on the ownership of the means of production into classes, and the inevitability of class conflict, inspired genocidal revolutionary movements and regimes that identified certain classes as exploiters and counter-revolutionaries who did not fit into the new revolutionary system and, therefore, had to be eliminated in genocidal purges in states such as the Stalinist Soviet Union and Democratic Kampuchea.

Ideological explanations are not always tied to modernity or the ideologically driven creation of radically new societies, however. Ben Kiernan's treatment of ideology suggests that while certain elements such as race thinking and the homogenization of populations on newly acquired or desired territories are modernist parts of the radical ideologies that underpin genocide, other elements of genocidal ideology are fundamentally anti-modern. For Kiernan, many genocidal regimes conceptualize the peasantry as the most "authentic" members of the political community, while cosmopolitan urban areas and their populations are considered to be "contaminated with foreign and decadent elements." 92 The goal for these genocidal 
elites is to recreate a glorious rural past through the genocidal destruction of peoples who are supposedly contaminating the pure peasantry and the countryside.

Ideology-based explanations point to the importance of ideas in the genocidal process as well as to the propensity for genocidal elites to categorize groups in society and to conceptualize their victims as alien and hostile to new or old revolutionary systems that must be purified of all deviant behavior, thought, or unworthy or inferior human beings. More than other explanations of genocide, the ideology approach also picks up the central role of threat perception, namely that genocidal elites come to see their victims not just as inferiors or misfits but as dangerous "enemies within." But, as with the modern state approach, the ideology variable cannot on its own account for why genocide, and not some other policy of repression or violence, occurs. Weitz, for example, lays out in great detail the conceptual origins of Nazi and radical Communist thought, but then, when it comes to the case studies of individual genocides, does not really account for why genocide was perpetrated against some groups and not others. In the case of the Holocaust, Weitz ties the Nazis' racist, social Darwinist ideology to the T4 eugenics program that targeted physically and mentally ill patients in Germany; the harsh treatment meted out against Poles, who were slated to became a vast pool of slave labor for the Nazis in the new German East during and after the war; and the Jews, who from the summer of 1941 onward were the objects of total extermination. thus, in his analysis, the same ideology explains three different policy outcomes.

\section{Process Explanations: Identity Construction}

While the approaches discussed thus far do at times refer to the processes by which genocide comes to be perpetrated, theories that concentrate on identity construction as the main explanatory variable are much more explicitly process-oriented approaches. When discussing the identity construction of the victim group by the perpetrators of genocide, the literature tends to group a number of different constructions under one generic label, such as "dehumanization" or "demonization." If we look carefully we can, in fact, identify three distinct yet interrelated processes of identity construction that scholars suggest lead to genocide: conceptions of the victims as an "alien" other; as sub- or non-humans; and as threatening "enemies within."

\section{Victims as other}

From a social psychological perspective, Chirot and McCauley argue that human beings have the capacity to "single out for genocide any kind of self-reproducing social category." 93 Humans categorize other human groups as "others" because we naturally divide the world into in-groups and out-groups characterized by their own distinct "essences." These essences, either one's own or another's, are regarded as "an unchanging quality that makes a group what it is." 94 For the authors, this dynamic of essentializing the identity of the other as different or foreign is a necessary part of the process of identity construction that leads to genocide, but it is not a sufficient condition on its own. Developing a similar social psychological approach, Waller notes the innate capacity of humans to divide the world into "us" and "them," which, under the right contextual and institutional conditions, helps lead to what he calls the "social death" of the victim, whereby the victim group is psychologically removed from the wider society. One of the features (along with dehumanization and blaming the victim) of the social death of the victims is the persistence of "us-them thinking."95 Waller also cites moderate, rather than radical or ideologically driven, feelings of antipathy toward 
the victim group and a "lack of emotional connection" with the victims as part of a dynamic that, in genocide, neutralizes popular aversion to authoritarian politics in general and the genocidal destruction of other groups in particular. ${ }^{96}$

In a frequently cited reference, Fein argues that one of the key preconditions for genocidal destruction is the removal of the victim group from the "sanctified universe of obligation." Referring specifically to the Armenians and Jews, Fein continues that the universe of obligations from which these groups were excluded was traditionally constituted by "that circle of people with reciprocal obligations to protect each other whose bonds arose from their relationship to a deity." The historical exclusion of the Armenians and Jews based on religious criteria set the precedent for the later secular conception of these groups as "strangers." 97 Fein's sociological analysis is significant because it points to two important dynamics. First, the exclusion of groups from society and their definition as aliens is not ahistorical but, rather, flows from already existing exclusionary practices and beliefs in society, although the exact content of these practices and beliefs may change over time. Second, the emphasis on reciprocity goes beyond inquiring into the tendency of human beings to see other human groups as simply different and imbeds the meaning of that conception of difference in a wider social context in which those who are deemed to belong are extended rights and mutual support while, as Herbert Hirsch and Roger W. Smith point out, ${ }^{98}$ those who are not are stripped of any protection, formal or informal, that membership in the community provides against a predatory state. The definition of the victim group as outsider, therefore, allows us to understand why bystanders wash their hands of a group to whom they believe they owe nothing and why perpetrators come to believe they can pursue their genocidal policies unopposed.

Taking the analysis further, Hirsch and Smith argue that defining the out-group through the use of myths not only marks one group off as different from other groups and apart from the wider society but also involves the dehumanization of the members of the group and culminates in calls for concrete action to bring about the group's extermination. ${ }^{99}$ For Waller, defining the victim group as other produces the "moral disengagement" of bystanders and perpetrators from the victims. This process entails an "active but gradual process of detachment" from the victims that exceeds mere moral indifference or invisibility and instead leads to the conceptual placing of the victim group "outside the boundary in which moral values, rules, and considerations of fairness apply." 100 As in Fein's analysis, this conception of the victim group leaves it cut off from society and thus vulnerable to all manner of abuses.

\section{Victims as sub- or non-human}

Categorizing groups into "us" and "them," or even into the more normative "us" versus "foreigner" or "stranger," is insufficient in and of itself to account for genocide. To understand why the physical destruction of the group becomes necessary from the perspective of the perpetrators, scholars who focus on identity construction look further, to conceptions of the victim groups as non-human. Once the victims are so conceived, the perpetrators can do anything to them, because the victims are seen to stand not only outside a particular political, national, ethnic, or racial community but outside of humanity itself.

In his pioneering work on the psychology of genocide, Israel Charny defines dehumanization as the act of redefining the victims of genocide as "not being part of the human species." ${ }^{101}$ For Chirot and McCauley, the perceptions of the different "essences" that mark off groups from one another can further give rise to more 
malevolent conceptions of the victim group as "not quite human." Conceptualized as non-human, the victims can thus be "used, abused, and eliminated as if they were another species of animal." "102 In his "eight stages of genocide" early-warning taxonomy, Gregory Stanton identifies dehumanization as integral to the genocidal process because the conception of the victim group as non human not only "denies the humanity of the other group" but also performs the crucial function of overcoming "the normal human revulsion against murder." ${ }^{103}$ As for which groups are most likely to be the target of dehumanization, Waller argues that the dehumanization of victim groups is most easily projected onto people belonging to different racial, ethnic, religious, or even political groups who are "regarded as inferior or threatening." 104 Chalk and Jonassohn similarly contend that genocide cannot happen to people who are regarded by their tormentors as equal to themselves or as fully human. The tendency to see outgroups as non-human is most apparent when "the differences between the people and some other society [are] particularly large." The tragic consequence of conceptualizing particular groups as "less than fully human," as "pagans, savages, or even animals," is the consequent understanding that the "values and the standards of the people" are not applicable to the out-group. ${ }^{105}$

The dehumanization of the victim group is likewise a necessary step in the genocidal process, for Waller, because it facilitates the "moral disengagement" of the perpetrator from the victim. This process involves not just indifference to the plight of the victims but "an active [...] gradual, process of detachment by which some individuals or groups are placed outside the boundary in which moral values, rules, and considerations of fairness apply." ${ }^{106}$ Charny similarly argues that dehumanization "aims at a redefinition of the other person as not deserving the protection due members of our species. Hence, anything and everything that is destructive of the other person, even killing, does not violate nature's design." Charny considers dehumanization to be both the "ideological justification" for genocidal killing and its ultimate "rationale."107 With respect to the perpetration of violence against the victims, Herbert Kelman contends that dehumanization is one of the processes by which the "usual moral inhibitions against violence become weakened," which, in turn, creates a context in which moral principles are believed to no longer apply to the victim, ${ }^{108}$ thus facilitating smooth and guilt-free killing.

\section{Victims as threat}

Finally, the identity construction literature focuses on perpetrators' conceptions of the victim group as a source of danger or threat that the perpetrators believe they must counter through the physical destruction of the victims. For strategic choice theorists like Valentino, the victims of genocide are conceptualized as a threat because they are seen to stand in the way of the realization of radical policy goals. For scholars who focus on identity construction specifically, perceptions of the threat believed to be posed by the victim group are said to be manifested in fear of the victim group, including fear of death in general and fear of lethal contamination and extermination in particular.

Charny argues that genocidal killing is an extreme but logical product of an all-toohuman process of projecting onto others that which we fear most. In genocide, the overwhelming fear of death itself is projected by the perpetrators onto the victims. The perpetrator thus kills his or her victims because "he believes he is justified in sparing himself death" by causing the death of others. ${ }^{109}$ Sharpening Charney's rather general explanation, Chirot and McCauley suggest that genocidal killers are motivated 
by specific fears that grow out of a more general fear of death. For these authors, fear of "pollution" is the "most extreme reason" for genocidal and mass killing and for other policies such as deportation. Here the victim group is seen to represent a "mortal danger" that must be removed from society in some way. This fear of pollution stems historically from concerns with religious purity, and in the twentieth century from concerns with racial and class purity. ${ }^{110}$

Perceptions of threat can also, according to Chirot and McCauley, produce other powerful emotions such as hatred of the victim group. Because the victim group is seen to be possessed of a "bad essence" (see above), that essence produces a hatred of the victim group grounded in a conception of the group as so "fundamentally flawed" that it "cannot be fixed." 111 As noted earlier, Chirot and McCauley point to a dynamic they call "double essentializing," in which a "battle" ensues between "good and evil," between the "two incompatible essences" of the perpetrators and the victims, in which the love for members of the in-group necessarily engenders hate for the threatening out-group. For Chirot and McCauley, the double essentializing dynamic is at the heart of the most extreme genocides. ${ }^{112}$

The conception of victims as threat is amplified by the perception of the victims as a powerful force bent on the extermination of the perpetrators, the state, society, the nation, the race, or a new revolutionary order. Given what is perceived to be the very real possibility of one's own extermination at the hands of the victim group, the latter must be exterminated first. Psychologist Robert Jay Lifton, for example, concludes his study of Nazi doctors at Auschwitz by suggesting that "[w]here the threat is so absolute and so ultimate [...] genocide becomes not only appropriate but an urgent necessity." 113 Lifton continues,

thus perceived as an absolute threat to the continuous life of one's own people, the victim group is seen as the bearer of death and therefore the embodiment of evil. More than merely non-human or heathen, it is dangerously anti-man and anti-God. Its disease takes the form of infecting others with death taint and deadly weakness. [...]

Only genocide, total elimination of the disease will protect one from that weakness.

The victim group "threatens one's own people with extinction so one must absolutely extinguish [them] first." 114 Chirot and McCauley argue that genocidal killers are motivated by the short-term fear that "failure to enforce vengeance will ultimately allow the enemy to regain strength and inflict further punishment" and by long-term fears of collective extermination at the hands of the victim group. ${ }^{115}$

The literature on identity construction contributes to our overall understanding of why and how genocide happens by demonstrating that perceptions of the victim group matter. Elites and ordinary people base their actions toward the victim group on how they perceive the identity of the victim group, because the interests and actions (past, present, and future) of the victim group are believed to rest on the group's collective identity. The existing literature, while promising, needs to be developed further to flesh out the exact relationship between collective identity construction, on the one hand, and the initiation and acceptance of genocidal policies, on the other. As it is, how exactly perceptions of the victim group lead to genocide, and not some other form of repression and violence, is treated in a rather general way. One possible avenue of inquiry is to explore the proposition that the relationship between collective identity construction, interests, and actions is a linear one whereby perpetrators believe that the identity of the victim group determines the group's interests, which, in turn, determines its actions. This perceived relationship between identity, interests, and actions could be what links perceptions of difference, 
non-humanness, and threat to the initiation, implementation, and acceptance of genocidal policies.

The identity construction literature also needs to consider more carefully how the identities of the victim group are constructed in the first place and how this construction can change over time. The works of Fein and of Hirsch and Smith serve as a starting point for exploring how the historic relationship between groups and perceptions of the nature of that relationship, particularly exclusionary attitudes toward the eventual victims of genocide, underpin later, more malevolent constructions of the victims as foreigners, enemies, threats, and subhuman vermin. We must also search for the triggers that turn generalized long-standing anti-group feelings, attitudes, and practices into the specific kinds of identity construction that are linked to genocide. Crises and the rise to power of highly ideological radical political elites are likely candidates for the transformation of the eventual victims of genocide from marginal insiders seen in a negative light to pernicious, threatening "enemies within" requiring extermination.

Finally, the literature sometimes appears to conflate what are in fact different but interrelated conceptions of the victim group. This conflation obscures our understanding of the specific functions that each of these conceptions plays in the genocidal process. Although this review groups the literature into three categories of identity construction (victims as outsiders, victims as non-humans, and victims as threat), genocidal scholars have a tendency to refer to disparate conceptions simultaneously, in an undifferentiated list of labels, as if they were all one and the same. Hirsch and Smith, for example, begin their stimulating analysis of language, myth, and genocide by suggesting that the first function of exclusionary language and myths is "defining the out-group." The label "defining the out-group" would seem to suggest a specific conception of the victim group as outsiders or foreigners, but the section begins with language that defines the victims not just as other or foreign but as "vermin, infidels, traitors, heretics, enemies of the people," all of which are said to loosen inhibitions against mass killing. ${ }^{116}$ Chalk and Jonassohn likewise argue that one of the key precursors to genocide is the perception that the victim group is not equal to, and fundamentally different from, the wider community. The conceptions of the victim group in the authors' analysis subsequently include references to the victims as "less than fully human" ("pagans, savages, and even animals"), "worthless, outside the web of mutual obligations, a threat to the people, immoral sinners, and/or sub/ human." 117 If we look at Hirsch and Smith and Chalk and Jonassohn's lists of conceptions of the victim group, we find that some of the conceptions are rather different from others. Some of them conceptualize the victims as outsider ("infidels," "heretics," "outside the web of mutual obligations"), some as sub- or non-human ("vermin," "less than fully human," "pagans," "savages," "animals," "worthless," "sub-human"), and some as threats ("enemies of the people," "a threat to the people").

Drawing distinctions among different perceptions of the victim group rather than treating them as different names for the same perception is important if, as suggested earlier, we argue that perceptions of identity determine perceptions of interests and future actions. Victims who are defined by the perpetrator group as outsiders or foreigners are seen to have fundamental interests that do not fit with those of the wider community. Victims who are defined as subhuman or as animals are seen to be so base as to be completely expendable. Victims who are conceptualized as threats are seen as powerful forces, as mortally imperiling the survival of the entire political community. It is this latter conception of the victim group that motivates genocide, 
not the dehumanization of the victims or seeing the victims as outsiders and foreigners. The last two conceptions are a necessary part of the genocidal process because they facilitate killing and because they separate the victims from the rest of society, respectively. But neither of these conceptions serves as the motivator for genocide, because they are too benign: non-humans are so low as to be nothing and, therefore, cannot constitute an overwhelming threat; groups conceived of as only outsiders or foreigners are believed to be non-members of the community and, therefore, are not owed rights or obligations, but this conception on its own does not threaten the community and does not require a genocidal response. Only the "mortal threat" conception of the victim group leads elites to initiate, and society to accept, genocidal policies, because only this conception requires elites and society to act to protect themselves from a threat whose continued existence is perceived to portend their own destruction if it is not first neutralized through genocidal policies.

\section{The Way Forward}

Comparative genocide theorizing has flourished over the last twenty years. Scholars from a variety of disciplines have produced theories to explain the genocidal behavior of elite and societal actors and have identified the big and small structures and processes that lead to genocide. What we need to do now is concentrate on how we theorize, specifically how we create comparative theories and how we test those theories using the comparative method.

As the review above has shown, many genocide scholars have already begun to generate theories in which the exact variables at play in the genocidal process are spelled out in great detail. We must continue this trend, and we must think very carefully, as we theorize, not just about the variables we think are associated with genocide but about precisely what the relationship is between the variables we think are important and under what conditions these variables produce genocidal policies or behavior. In doing so, we should clearly state whether we are making deterministic claims (A, B, and C cause D) or whether we are making probabilistic claims ( $\mathrm{D}$ is more likely to occur when A, B, and C occur under a specific set of circumstances). Once the relevant variables and the relationship between them are identified, we should further indicate precisely what empirical indicators we will use to illustrate each variable and to measure the effect of each variable. Here we need to demonstrate what evidence in each case will be used as a measure of a given variable and why we think that evidence is comparable to evidence measuring the same variable in other cases. If we do this, scholars and readers can be more confident that the evidence cited really does measure the variables under investigation and that we are making valid and stable comparisons across cases, rather than telling general narratives in support of theoretical claims.

Methodological discussions, to date, have tended to revolve for the most part around which cases we can compare based on a specific definition and which cases we cannot compare because they do not constitute genocide. This is always an important, albeit divisive, part of the comparative process and needs to continue. Beyond this, however, we need to begin to evaluate the comparison of cases based on other, more strictly comparative methodological criteria. Scholars need to explicitly consider the relative merits and limitations of ideographic (single-case-study) versus nomothetic (multiple-case-study) theorizing and comparisons. Ideographic studies can still be comparative, so long as the theories they generate and test can be generalized, at least to a certain degree, to explain similar cases. Nomothetic comparisons, of which we are 
seeing more and more, should contemplate the relative advantages and disadvantages of intensive comparisons (a small number of cases and a large number of variables) versus extensive comparisons (a large number of cases and a small number of variables). The former approach currently represents most genocide case comparisons. These sorts of comparisons allow for the "thick" description and analysis of a small number of cases using theories that include a number of variables designed to explain the vast complexity of the cases; this approach, however, is limited in terms of generalizability. The latter approach, adopted by Barbara Harff, for example, eschews "thick" description in favor of relatively parsimonious theories of genocide and politicide tested against a very large number of cases in order to construct and test much more general theories of genocide and politicide. Whichever approach scholars use, we need to justify why we have taken the approach we have and why we think it contributes to our knowledge of genocide.

Finally, when we choose our cases, we should state whether we are engaging in what Adam Przeworski and Henry Teune call "most similar systems" or "most different systems" comparisons. ${ }^{118}$ As Przeworski and Teune tell us, most similar comparisons are the most effective and reliable comparisons, because they control for a wide number of variables, allowing the researcher to test the effect of variation in only a small number of variables. Most different comparisons, on the other hand, are comparisons in which there is a number of differences across each case but where a few key variables are the same. This kind of comparison also tests how much variation across cases of genocide a theory can explain. Like ideographic versus nomothetic comparisons, most similar and most different comparisons have their pros and cons. It is up to genocide scholars to decide which approach is most appropriate and, again, to justify why a most-similar or most-different approach is amenable to each scholar's research question, theoretical approach, and available evidence. Manus Midlarsky's The Killing Trap (a nomothetic study) and Scott Straus's The Order of Genocide (an ideographic study) are leading examples of the ways in which genocidal scholars in the social sciences should be thinking through comparative theoretical and methodological issues and problems when creating and testing comparative theories.

Sound theory, methodology, and research in comparative genocide studies are of value as an academic enterprise, but they should also be an important foundation for the formulation of effective strategies for genocide prevention and reconciliation after genocide. As a goal-oriented project, genocide studies must find a way to bridge the gap between abstract theorizing, on the one hand, and concrete policy making and implementation, on the other. Although our theories may tell us that factors such as human social psychology, societal fragmentation, various forms of crises, radical exclusionary ideologies, and conceptions of collective identity lead to genocide, how to turn this knowledge into concrete workable policies in real life and real time is not entirely obvious. Generalizability, while a desirable goal for comparative research, is not necessarily the goal with respect to crafting policies for prevention and, when required, intervention. Grand schemes to remake societies at greater risk of genocidal violence will be futile if they are one-size-fits-all policies or if they envision massive and sustained intervention in the domestic affairs of sovereign states by other states, intergovernmental organizations, or non-governmental organizations. No matter how passionate genocide scholars are about finding ways to prevent genocide, prescriptions for prevention that fail to take into account the realities of sovereignty, the cold hard realpolitik of international relations, and the real economic costs (not to mention the question of who will pay those costs) are not worth the effort. Genocide scholars, 
activists, and policy makers may also have to confront the very real possibility that regimes bent on waging "final solutions" against their perceived enemies may not be swayed by what the outside world thinks or does.

Similarly, strategies for fostering reconciliation in societies that have experienced genocide must avoid totalizing approaches that fail to recognize the particularities of individual cases. Approaches to reconciliation must, of course, take into account what we know in general about group dynamics in genocidal situations in order to move beyond them, but our prescriptions must first and foremost focus on culturally and situationally specific conditions and the concrete reality of individual and group dynamics on the ground. We must also take a good hard look at what reconciliation strategies have and have not worked, why they have or have not worked, where they have been successful and not, who has benefited and who has not. As in the case of prevention, crafting strategies for reconciliation is not the exclusive purview of genocide scholars. Prevention and reconciliation are collaborative projects that, by necessity, involve policy makers, activists, professionals, survivors, victims' families and communities, and the perpetrators or would-be perpetrators.

In sum, comparative genocide theory has come a long way in a short time. As in all disciplines and subjects in the social sciences and humanities, there is more work to do. But we should never forget that comparative genocide studies is far more than the scholarly pursuit of theory, testing, and generalization. We must remember the harsh reality of what it is we are really trying to do: to discover, bit by bit, why humanity continues to perpetrate this terrible crime, and why it is that innocent men, women, and children, simply because they continue to exist, fall victim to this "old scourge."

\section{Notes}

1. For a review essay on the state of comparative genocide research see Scott Straus, "Second Generation Comparative Research on Genocide," World Politics 59 (2007): 476-501.

2. This article also leaves aside discussions of typologies in the literature, again because they have been discussed elsewhere, but also because typologies are primarily an exercise in categorization. While typologies do hold some important explanatory power, they are, like definitions of concepts, a foundation upon which theories are constructed, not theories in and of themselves.

3. This characterization of comparative genocide studies is based on David Laitin's similar observation on the current state of comparative politics: David D. Laitin, "Toward a Political Science Discipline: Authority Patterns Revisited," Comparative Political Studies 13 (1998): 423-43.

4. Gerald Fleming, Hitler and the Final Solution (Berkeley: University of California Press, 1982).

5. See, e.g., David P. Chandler, Brother Number One: A Political Biography of Pol Pot, rev. ed. (Boulder, CO: Westview Press, 1999); Ian Kershaw, Hitler 1936-1945: Nemesis (London: Allen Lane/ Penguin, 2000).

6. Benjamin A. Valentino, Final Solutions: Mass Killing and Genocide in the 20th Century (Ithaca, NY: Cornell University Press, 2004); Manus I. Midlarsky, The Killing Trap: Genocide in the Twentieth Century (Cambridge: Cambridge University Press, 2005).

7. Valentino, Final Solutions, 4, 72-73.

8. Daniel Chirot and Clark McCauley, Why Not Kill Them All?: The Logic and Prevention of Mass Murder (Princeton, NJ: Princeton University Press, 2006), 20, 2.

9. Theodor W. Adorno, Else Frenkel, and Daniel J. Levinsons, The Authoritarian Personality: Studies in Prejudice, abridged ed. (New York: W.W. Norton, 1993). 
10. Chirot and McCauley, Why Not Kill Them All?; James Waller, Becoming Evil: How Ordinary People Commit Genocide and Mass Murder (Oxford: Oxford University Press, 2002); Alex Alvarez, Governments, Citizens, and Genocide: A Comparative and Interdisciplinary Approach (Bloomington: Indiana University Press, 2001).

11. Chirot and McCauley, Why Not Kill Them All?, 20-44.

12. Ibid., 52 .

13. Ibid., 90.

14. Ibid., 61.

15. Ibid., 86.

16. Waller, Becoming Evil, 19-20.

17. Alvarez, Governments, Citizens, and Genocide, 110.

18. Ibid., 114-28.

19. Because Alvarez takes a structural rather than an agency-centered approach with respect to institutions, the review of his analysis of the modern state and state institutions as principal perpetrators of genocide is covered below, in the section on structural theories.

20. See Adorno et al., The Authoritarian Personality.

21. See, e.g., Ervin Staub, The Roots of Evil: The Psychological and Cultural Origins of Genocide and Other Forms of Group Violence (Cambridge: Cambridge University Press, 1989).

22. Daniel Jonah Goldhagen, Hitler's Willing Executioners: Ordinary Germans and the Holocaust (New York: Vintage Books, 1997).

23. Alexander Laban Hinton, Why Did They Kill? Cambodia in the Shadow of Genocide (Berkeley: University of California Press, 2005).

24. Alexander Laban Hinton, "A Head for an Eye: Revenge in the Cambodian Genocide," American Ethnologist 25 (1998): 352-77, 353.

25. Ibid., 353.

26. Christopher C. Taylor, "The Cultural Face of Terror in the Rwandan Genocide of 1994," in Annihilating Difference: The Anthropology of Genocide, ed. Alexander Laban Hinton, 137-78 (Berkeley: University of California Press, 2002), 139.

27. Omer Bartov, "Seeking the Roots of Modern Genocide: On the Macro and Microhistory of Mass Murder," in The Specter of Genocide: Mass Murder in Historical Perspective, ed. Robert Gellately and Ben Kiernan, 75-96 (Cambridge: Cambridge University Press, 2003), 85.

28. Jan Tomasz Gross, Neighbors: The Destruction of the Jewish Community in Jedwabne, Poland, (Princeton, NJ: Princeton University Press, 2001).

29. Leo Kuper, Genocide (New Haven: Yale University Press, 1981), 57.

30. Ibid., 58 .

31. Richard G. Hovannisian, "Etiology and Sequelae of the Armenian Genocide," in Genocide: Conceptual and Historical Dimensions, ed. George J. Andreopoulos, 111-40 (Philadelphia: University of Pennsylvania Press, 1994), 112.

32. Kuper, Genocide, 59.

33. Alexander Laban Hinton, "The Dark Side of Modernity: Toward an Anthropology of Genocide," in Annihilating Difference: The Anthropology of Genocide, ed. Alexander Laban Hinton, 1-42 (Berkeley: University of California Press, 2002), 29.

34. Helen Fein, "Accounting for Genocide after 1945: Theories and Some Findings," International Journal on Group Rights 1 (1993): 88-92.

35. Helen Fein, "Revolutionary and Anti-revolutionary Genocides: A Comparison of State Murders in Democratic Kampuchea, 1975 to 1979, and in Indonesia, 1965 to 1966,” Comparative Studies in Society and History 35 (1993): 796-823.

36. See, e.g., Valentino, Final Solutions, 16-22. Valentino cites large-scale quantitative studies including James D. Fearson and David D. Laitin, "Ethnicity, Insurgency and Civil War," American Political Science Review 97 (2003): 75-90; Matthew Krain, "State Sponsored Mass Murder: The Onset and Severity of Genocides and Politicides," Journal of Conflict Resolution 41 (1997): 331-60; Barbara Harff, "No Lessons Learned from the Holocaust? 
Assessing Risks of Genocide and Political Mass Murder Since 1955," American Political Science Review 97 (2003): 67-68. While these kinds of studies are useful, they attempt to control for, and, therefore, factor out as much as possible, the effect of contextual factors. They are also much more vulnerable to coding errors because of the sheer number of cases and the lack of specific expertise by the researcher(s) in most of the cases in the comparison.

37. This argument is the inverse of Robert Putnam's thesis that democratic institutions work best in an environment of "civic engagement" characterized by a high degree of solidarity, trust, and tolerance between groups in society and a rich associational life that cuts across communal cleavages. Robert D. Putnam, Making Democracy Work: Civic Traditions in Modern Italy (Princeton, NJ: Princeton University Press, 1993), 167-76.

38. Helen Fein, Accounting for Genocide: National Responses and Jewish Victimization During the Holocaust (Chicago: University of Chicago Press, 1979), 9.

39. Midlarsky, The Killing Trap, 103-7.

40. Florence Mazian, Why Genocide: The Armenian and Jewish Experiences in Perspective (Ames: Iowa University Press, 1990), 145, 21-42, 145-56.

41. Staub, The Roots of Evil, 107-10.

42. Hinton, "The Dark Side of Modernity," 29.

43. Harff, "No Lessons Learned," 66.

44. Chirot and McCauley, Why Not Kill Them All?, 94.

45. Tarrow developed this concept to account for the rise and timing of social movements. Sidney Tarrow, Power in Movement: Social Movement, Collective Action, and Politics (Cambridge: Cambridge University Press, 1994).

46. Lucy S. Dawidowicz, The War Against the Jews: 1933-1945 (New York: Bantam Books, 1975).

47. Alexander Wendt, "Anarchy Is What States Make of It: The Social Construction of Power Politics," International Organization 46 (1992): 391-425.

48. Robert F. Melson, Revolution and Genocide: On the Origins of the Armenian Genocide and the Holocaust (Chicago: University of Chicago Press, 1992), 260, 267.

49. Edward Kissi, Revolution and Genocide in Ethiopia and Cambodia (Lanham, MD: Lexington Books, 2006), 79-120.

50. Eric Markusen, "Genocide and Total War: A Preliminary Comparison," in Genocide and the Modern Age: Etiology and Case Studies of Mass Death, ed. Isidor Wallimann and Michael N. Dobkowski, 97-123 (Syracuse, NY: Syracuse University Press, 1987); Eric Markusen and David Kopf, The Holocaust and Strategic Bombing: Genocide and Total War in the Twentieth Century (Boulder, CO: Westview Press, 1995), 55-92.

51. Markusen and Kopf, The Holocaust and Strategic Bombing, 64.

52. Ibid.

53. Ibid., 65.

54. Scott Straus, The Order of Genocide: Race, Power, and War in Rwanda (Ithaca, NY: Cornell University Press, 2006), 7.

55. Omer Bartov, Mirrors of Destruction: War, Genocide, and Modern Identity (Oxford: Oxford University Press, 2000), 18.

56. Ibid., 12 .

57. Ibid., 29 .

58. Martin Shaw, War and Genocide: Organized Killing in Modern Society (Cambridge: Polity Press, 2003), 5.

59. Ibid., 27.

60. Ibid., 44-45.

61. Ibid., 28.

62. Ibid., 46 .

63. Ibid., 28.

64. Convention on the Prevention and Punishment of the Crime of Genocide, 9 December 1948, 78 U.N.T.S. 277, http://www.unhchr.ch/html/menu3/b/p_genoci.htm (accessed 18 September 2008), art. 2. 
65. Helen Fein, Genocide: A Sociological Perspective (London: Sage, 1993), x (emphasis added).

66. Frank Chalk and Kurt Jonassohn, The History and Sociology of Genocide: Analyses and Case Studies (New Haven: Yale, 1990), 23 (emphasis added).

67. Israel W. Charny, "Toward a Generic Definition of Genocide," in Genocide: Conceptual and Historical Dimensions, ed. George J. Andreopoulos, 64-94 (Philadelphia: University of Pennsylvania Press, 1994), 75 (emphasis added).

68. Irving Horowitz, Taking Lives: Genocide and State Power, 4th ed. (New Brunswick, NJ: Transaction Publishers, 1997).

69. Hannah Arendt, Origins of Totalitarianism (New York: Harcourt Brace, 1979), 437-59.

70. The label "totalitarian," as distinct from authoritarianism, has always been controversial, as it has not always been clear that actually existing regimes usually labeled totalitarian, such as Nazi Germany or Stalinist Russia, really achieved the total penetration of all aspects of life suggested by prevailing theories of totalitarianism.

71. Rudolph J. Rummel, Death by Government (New Brunswick, NJ: Transaction Publishers, 1994), 1-2.

72. Harff, "No Lessons Learned," 66.

73. In one of his early works, Robert Putnam refers to these kinds of elites as "conflict-oriented politicians" for whom conflict is highly salient. They are likely to be "fragmented and paralyzed, for their cognitive lenses magnify conflicting interests and minimize mutual interest." The interpersonal orientation of these elites is riven by "personal and partisan antagonism," a "culture of conspiracy, mutual suspicion and cynicism." Robert Putnam, The Comparative Study of Political Elites (Englewood Cliffs, NJ: Prentice Hall, 1976), 86.

74. Zygmunt Bauman, Modernity and the Holocaust (Ithaca, NY: Cornell University Press, 1989), 98-111.

75. Ibid., 66-76.

76. Alvarez, Governments, Citizens, and Genocide, 57, 59.

77. Ibid., 59 .

78. Ibid.

79. Ibid., 63.

80. Ibid., 71-78.

81. Ibid., 93, 94-97.

82. Ibid., 97-100.

83. See, e.g., Straus, The Order of Genocide.

84. Chalk and Jonassohn, The History and Sociology of Genocide, 37-40; Helen Fein, "Revolution and Anti-Revolutionary Genocides: A Comparison of State Murders in Democratic Kampuchea, 1975-1979 and in Indonesia, 1965-1966," Comparative Studies in Society and History 35 (1993): 796-823; Peter du Preez, Genocide: The Psychology of Mass Murder (London: Boyars/Bowerdean, 1994), 28-47.

85. Eric D. Weitz, A Century of Genocide: Utopias of Race and Nation (Princeton, NJ: Princeton University Press, 2003).

86. Hinton, "Toward an Anthropology of Genocide," 8.

87. Ibid., 12-13.

88. Weitz, A Century of Genocide, 17-31.

89. Ibid., 45-46.

90. Ibid., 39 .

91. Ibid., 47.

92. Ben Kiernan, "Twentieth Century Genocides: Underlying Ideological Themes from Armenia to East Timor," The Specter of Genocide: Mass Murder in Historical Perspective, ed. Robert Gellately and Ben Kiernan, 29-52 (Cambridge: Cambridge University Press, 2003), 29, 33, 40-45. Also see Ben Kiernan, Blood and Soil: A World History of Genocide and Extermination from Sparta to Darfur (New Haven, CT: Yale University Press, 2007).

93. Chirot and McCauley, Why Not Kill Them All?, 82.

94. Ibid., 82.

95. Waller, Becoming Evil, 19-20. 
96. Ibid., 43.

97. Fein, Accounting for Genocide, 4-5.

98. Herbert Hirsch and Roger W. Smith, "The Language of Extermination in Genocide," in Genocide: A Critical Bibliographic Review, vol. 2, ed. Israel W. Charny, 386-403 (London: Mansell Publishing, 1991), 387.

99. Ibid., 388-91.

100. Waller, Becoming Evil, 186.

101. Israel W. Charny, How Can We Commit the Unthinkable? Genocide: The Human Cancer (Boulder, CO: Westview Press, 1982), 207.

102. Chirot and McCauley, Why Not Kill Them All?, 84-85.

103. Gregory H. Stanton, "The 8 Stages of Genocide," Genocide Watch (1998), http://www. genocidewatch.org/aboutgenocide/8stages.htm (accessed 18 September 2008).

104. Waller, Becoming Evil, 20, 245.

105. Chalk and Jonassohn, The History and Sociology of Genocide, 28.

106. Waller, Becoming Evil, 20.

107. Charny, How Can We Commit the Unthinkable?, 206-7.

108. Herbert C. Kelman, "Violence Without Moral Restraint: Reflection on the Dehumanization of Victims by Victimizers," Journal of Social Issues 294 (1973): 25-61. 48-49.

109. Charny, How Can We Commit the Unthinkable?, 186, 192.

110. Chirot and McCauley, Why Not Kill Them All?, 36-42.

111. Ibid., 72-73.

112. Ibid., 86.

113. Robert Jay Lifton, The Nazi Doctors: Medical Killing and the Psychology of Genocide (New York: Basic Books, 1986), 477.

114. Ibid., 479.

115. Chirot and McCauley, Why Not Kill Them All?, 31-32.

116. Hirsch and Smith, "The Language of Extermination in Genocide," 388.

117. Chalk and Jonassohn, The History and Sociology of Genocide, 28.

118. Adam Przeworski and Henry Teune, The Logic of Comparative Social Inquiry (New York: Wiley, 1970), 31-46. 